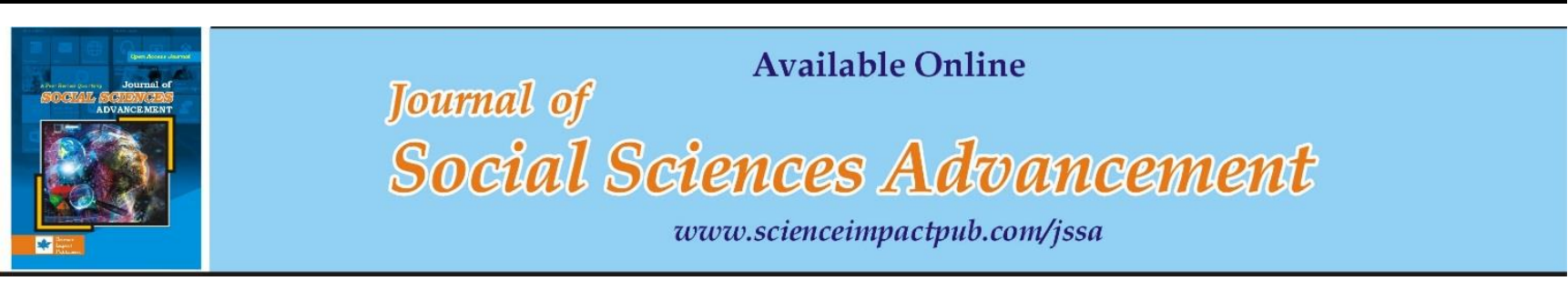

\title{
Stakeholders' Perceptions regarding the use of Hologram for Educational Purposes in District Toba Tek Singh, Pakistan
}

\author{
Muhammad Hasan Rehman', Muhammad Shahbaz ${ }^{2}, \operatorname{Rana}^{1}$ Mhammad Amir ${ }^{*}$, Hafiz Ali Raza ${ }^{*}$ and \\ Ayesha Kanwel ${ }^{1}$ \\ ${ }_{1}^{1}$ Institute of Agri. Extension, Education and Rural Development, University of Agriculture, Faisalabad, Punjab, Pakistan \\ 2The School of Engineering \& the Built Environment, Edinburgh Napier University, UK
}

\begin{abstract}
Hologram is essential in education because it is more helpful for students to clear their concepts through moving objects and engaging many students. Different hologram types are used in various educational institutes such as reflection holograms, transmission holograms, and pyramid holograms. It is an exciting and widely discussed tool in the world. ICTs are frequently used, such as computers, laptops, projectors, smart boards, and other audiovisual aids. The study's purpose was to attain stakeholders' perceptions regarding the use of holograms for educational purposes in District Toba Tek Singh, Punjab, Pakistan. The total sample size of 116 respondents were selected from the population by using a simple random sampling technique. The results indicated that most of the respondents were agreed that the strengths of hologram technology could be meaningful in the teaching-learning process. It is also concluded that students fear new technology will be less and more time-saving due to hologram technology use in the teaching-learning process. It also discovered that lack of leadership's quality was a significant barrier to adopting hologram technology in the education system.
\end{abstract}

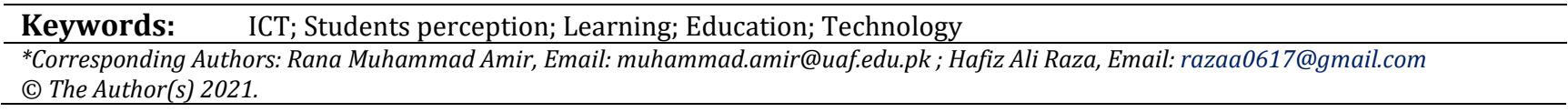

\section{INTRODUCTION}

In simple terms, hologram technology is a three-dimensional projection that can be perceived without the use of a special device such as cameras or glasses. The image can be viewed from any angle, so as the user walks around the screen, the object will appear to be moving and shifting realistically. Holographic images can be static, such as an image of an invention, or they can be moving sequences that can be watched by many people from any angle.

The technology used to capture and display holograms has been rapidly innovating in recent years. These latest techniques allow for the emergence of larger and more interactive models and, predictably, they will become even more widespread in the future. The hologram looks so realistic because it is an accurate record of the light waves reflected from the object. Different lasers can produce different colors of an object. The most widely used type of laser is the sun-neon.

Although some of them are made of red laser pointer diodes, they are generally unstable and less cohesive (Cruz et al., 2016). Different holograms can be used for other educational levels, as there are now different holograms, such as reflection holograms, transmission holograms and pyramidal holograms (Ramachandiran et al., 2019). Holography significantly disrupts 3D images, as it offers better usability and addresses the weaknesses of 3D solutions. It can potentially affect every aspect of life, but paradoxically, it can change the game in the medical industry (Mishra, 2017).

You can interact with the researcher in real-time and everyone seems to be in the same room. Researchers and teachers would use verbal communication, body language and virtual images to share and exchange information (Caggianese, 2018). Technology integration means applying educational technology to inspire positive teaching methods to facilitate students' learning and increase their ability, productivity and performance in their learning process (Lee, 2013). In the educational system, information and communication tools are used often from recent times, such as computers, smartboards, cell phones, projectors, audiovisual media, aids, etc. in the teaching and learning process (Devi et al., 2019).

Recently, technological developments have played a fundamental role in improving the educational process. For example, many academic institutions use advanced technological tools, such as touch screens, new software, and other students (Law, 2021). Students improve their understanding of the meaning of learning topics, especially in the fields of medicine and engineering, to better understand what they remember. We can apply 3D hologram technology 
to any educational level (pre-school, primary and secondary education and tertiary education). This can transcend the slow adaptation of technology to the education system (Elmarash et al., 2021).

Holographic teleshopping technology has opened the door to new possibilities for an unimaginable level of commitment and enthusiasm in the learning process that engages and encourages students (Venditti and Mele, 2020). It has to do with human skills and abilities. Three main elements must be involved effectively to ensure a better result. These are the teacher, the student, and the appropriate educational environment. Using 3DHT, it is possible to achieve the same real-world training goals (Abdelhamid, 2020).

This is done to help students understand learning content more effectively than using these traditional approaches, according to the Industrial Revolution. As students are more favorable to the use of technology, teachers should take a step forward Feng and Yamat, (2019). The Ministry of Education should also provide adequate facilities for educational institutions to make effective use of technology (Halili, 2019).

Healthy lifestyle and learning flexibility had affected mental health when examining the relationship between the two variables (Nur Arif Syazana, 2019).

\section{Objectives of the Study}

The objectives are to:

- Identify the strengths of the hologram in teaching and learning.

- Identifying opportunities for the use of holograms in the field of education.

- Identification of obstacles in the adoption of hologram technology in the educational system

\section{Research Questions}

The questions of the research are:

- Strengths of hologram technology in the teaching-learning process

- Opportunities of Hologram in the education sector

- Barriers in the adoption of hologram technology in the education system

\section{MATERIALS AND METHODS}

Toba Tek Singh is a city and district of Pakistan's Punjab province. It was separated as a district in 1982 and it is located in the center of Punjab province of Pakistan. Parveen et al., (2021) suggested that the teachers and students take part equally for quality of education which can indicate the positive performance of the students. Wang et al., (2021) reported that teachers' instructions completely depend on students' perception and it's a huge challenge for the teachers how they tackle the recent situation. Survey-based research was conducted in this study because survey research has a high response rate compared to others (Parveen and Tran 2020; Aslam et al., 2021). Purposively secondary school science subjects were selected from tehsil Toba Tek Singh because various diagrams are present in science subjects. Teachers feel difficulty explaining all the parts of the diagram and clarifying students' concepts.

\section{Population}

It is a large group of people where they live together (Taherdoost, 2016). The target population is the hypothetical set of individuals, objects, or events that are the actual participants, and the researchers have a desire to generalize/simplify the outcomes of the study. The population is the totality of the subjects out of which a sample is taken for the research purpose. The population of this research was all the science teachers at secondary school (166 teachers).

\section{Sampling}

Sampling is described to be the sub-group of the population to gather information from the respondents (Aslam et al., 2020; Phuc et al., 2020). The sample for this study has been drawn by the simple random sampling technique. A total of 116 teachers were selected from the population.

\section{Research Procedure}

Shafiq et al., (2018) suggested the method to design a well-structured close-ended questionnaire that was designed for gathering information from the respondents. Data were analyzed with the help of the computer software Statistical Package of Social Sciences (SPSS) for an effective conclusion (Shafiq et al., 2020). 


\section{RESULTS AND DISCUSSIONS}

Table 1: Distribution of the respondents according to strengths of hologram technology in the teaching-learning process

\begin{tabular}{|c|c|c|c|c|}
\hline Statement & Weighted score & Mean & STD & Rank order \\
\hline Students fear toward new technology will be less & 224 & 1.93 & 0.74 & 1 \\
\hline Time saving process & 223 & 1.92 & 0.83 & 2 \\
\hline It is a source to entertain the students & 215 & 1.85 & 0.68 & 3 \\
\hline Students' academic achievement will increase with the use of Hologram & 211 & 1.82 & 0.67 & 4 \\
\hline Student's interest will increase toward Learning & 209 & 1.80 & 0.53 & 5 \\
\hline Learning by seeing have a long-term memory & 207 & 1.78 & 0.49 & 6 \\
\hline Learning will enhance with the use of Hologram & 207 & 1.78 & 0.49 & 7 \\
\hline Capable to engage large class & 206 & 1.78 & 0.62 & 8 \\
\hline It will clear students' concepts more than books & 201 & 1.73 & 0.53 & 9 \\
\hline Students like moving objects in Learning & 194 & 1.67 & 0.49 & 10 \\
\hline
\end{tabular}

Nadila et al., (2021) recommended that smart 3D Hologram is reflected as the most innovative technology that gives several benefits in education such as helping teachers and students. Table 1 showed that most of the respondents were agreed that the following strengths of hologram technology could be meaningful in the teaching-learning process e.g., students fear toward new technology will be less; also a source to entertain the students, students' academic achievement will increase with the use of hologram, students interest will increase toward learning, learning by seeing have a long term memory, learning will enhance with the help of hologram, capable to engage large class, it will clear students concept more than books, students like moving objects in learning were rated with mean value $1.93,1.92,1.85,1.82,1.80,1.78,1.78,1.78,1.73,1.67$ respectively.

Table 2: Distribution of the respondents according to opportunities of hologram in the education sector

\begin{tabular}{|c|c|c|c|c|}
\hline Statement & Weighted score & Mean & STD & Rank order \\
\hline Peer group importance will increase & 213 & 1.84 & 0.71 & 1 \\
\hline Small content and greater information communication & 211 & 1.82 & 0.79 & 2 \\
\hline Difficulties of the drawing will have vanished & 208 & 1.79 & 0.58 & 3 \\
\hline Teaching from books is easier than technology & 206 & 1.78 & 0.79 & 4 \\
\hline Special training courses will be required regarding the use of hologram & 200 & 1.72 & 0.63 & 5 \\
\hline Special setup and classroom will be required for communication & 197 & 1.70 & 0.62 & 6 \\
\hline The curiosity of students will increase related to hologram images & 193 & 1.66 & 0.49 & 7 \\
\hline This technology is best for graduation and master level & 190 & 1.64 & 0.65 & 8 \\
\hline With more explanation, learning will enhance & 189 & 1.63 & 0.55 & 9 \\
\hline Teachers and students will play an active role in the classroom & 177 & 1.53 & 0.52 & 10 \\
\hline
\end{tabular}

Table 2: shows that the majority of the respondents were in favor that the following opportunities of hologram could be useful in the education system such as peer group importance will increase, small content and greater information communication, difficulties of the drawing will vanish, teaching from books is easier than technology, special training courses will be required regarding use hologram and special setup and classroom students will play an active role in the classroom were rated with mean value 1.84, 1.82, 1.79, 1.78, 1.72, 1.70, 1.66, 1.64, 1.63, 1.53 respectively. Pradhan et al., (2021) reported that the education system can be enhanced through active teaching and learning environment for this purpose teachers can help through the latest technologies or it may b possible through practices. Matere et al., (2021) suggested that virtual classrooms show interactive systems which may act not only for teachers but also students as well.

Table 3: Distribution of the respondents according to barriers in the adoption of hologram technology in the education system

\begin{tabular}{lcccc}
\hline Statement & Weighted score & Mean & STD & Rank order \\
\hline Lake of leadership & 389 & 2.01 & 0.55 & 1 \\
Lake of coordination among teachers and stakeholders & 386 & 2.00 & 0.66 & 2 \\
Lack of vision & 376 & 1.98 & 0.56 & 3 \\
Caring of the hologram & 254 & 1.97 & 0.72 & 4 \\
Non-teaching assignments for teachers & 242 & 1.95 & 0.63 & 5 \\
Burden of more classroom & 234 & 1.92 & 0.74 & 6 \\
Budget for education & 233 & 1.75 & 0.59 & 7 \\
Repairing problem & 232 & 1.70 & 0.56 & 8 \\
Preparation of lecture on hologram & 230 & 1.68 & 0.49 & 9 \\
Corruption is a big issue & 229 & 1.67 & 0.54 & 10 \\
Expensive technology & 226 & 2.01 & 0.55 & 11 \\
Electricity is a big problem & 223 & 2.00 & 0.66 & 12 \\
Over loaded classroom is big problem & 203 & 1.98 & 0.56 & 13 \\
High-speed internet will be required & 197 & 1.97 & 0.72 & 14 \\
Trainee availability & 195 & 1.95 & 0.63 & 15 \\
Time to learn new technology & 194 & 1.92 & 0.74 & 16 \\
\hline
\end{tabular}

Table 3 shows that the majority of the respondents were agreed that the following barriers are the cause to adopt the hologram technology in the education system i.e. lake of leadership, the lack of coordination among teachers and stakeholders, lack of vision, caring of the hologram, non-teaching assignments for teachers, the burden of more 
classroom, budget for education, repairing the problem, preparation of lecture on the hologram, corruption is a big issue, expensive technology, electricity is a big problem, an overloaded classroom is a big problem, high-speed internet will be required, trainee availability, time to learn new technology were rated with mean value 2.01, 2.00, $1.98,1.97,1.95,1.92,1.75,1.70,1.68,1.67,2.01,2.00,1.98,1.97,1.95$ and 1.92 respectively. Matsika et al., (2021) suggested that the main reasons which affect the teaching and learning process, first of all, there is no synchronization while making educational policies, teachers face difficulties while using new and advanced technologies.

\section{CONCLUSIONS}

It is concluded that students hesitate to touch and use the expensive things available in school due to feeling of punishment by the teachers. Some barriers exist in the adoption of hologram in education they are as follows, it is an expensive technology the poor countries are not able to provide in all the schools, as a very little budget they offer for education sectors a bit resistance is present towards new technology as it needs the training to modify the psychology toward innovating equipment's which is helpful in the teaching-learning process. Hologram technology requires high-speed internet for better communication it is also a barrier to the adoption of the hologram. The results indicated that students fear new technology will be less and more time-saving due to hologram technology use in the teachinglearning process.

\section{REFERENCES}

Abdelhamid, M. (2020). Using 3D Hologram Technology (3DHT) in the Distance Learning Program to Enhance the Professional Skills of Tour Guidance Undergraduate Students. Journal of Association of Arab Universities for Tourism and Hospitality, 18(3), 17-34.

Aslam, S., Akram, H., \& Parveen, K. (2020). Cultural Differences and Problems: A case of International Students Studying in a Normal University in North China. Journal of Social Sciences Advancement, 1(01), 08-12.

Aslam, S., Saleem, A., Akram, H., Parveen, K., \& Hali, A. U. (2021). The challenges of teaching and learning in the COVID19 pandemic: The readiness of Pakistan. Academia Letters, 2.

Caggianese, G., Gallo, L., \& Neroni, P. (2018). Evaluation of spatial interaction techniques for virtual heritage applications: a case study of an interactive holographic projection. Future generation computer systems, 81, 516527.

Cruz, F. J. F., \& Díaz, M. J. F. (2016). Generation z's teachers and their digital . skills. Comunicar. Media Education Research Journal, 24(1).

Devi, K. K., \& Verma, M. K. (2019). Content evaluation and the design trends of national institutes of technology (NITS) library websites of India: an evaluative study. Journal of Indian Library Association, 53(2\&3).

Elmarash, G. A., Adrah, M. M., \& Eljadi, E. E. (2021). 3D Hologram Technology in Libyan Educational Institutions in Future: Re-view. Journal of Pure \& Applied Sciences, 20(3), 6-10.

Feng, C. K., \& Yamat, H. (2019). Testing on the validity and reliability of task based language teaching questionnaire. International Journal of Academic in Research Business and Social Sciences, 9(12), 347-358.

Halili, S. H. (2019). Technological advancements in education 4.0. The Online Journal of Distance Education and eLearning, 7(1), 63-69.

Kruss, G., McGrath, S., Petersen, I. H., \& Gastrow, M. (2015). Higher education and economic development: The importance of building technological capabilities. International Journal of Educational Development, 43, 22-31.

Law, E. L. C. (2021, October). Augmented Reality Educational Applications: Let's find out what students and teachers need!. In Actas del Congreso Internacional de Ingeniería de Sistemas (pp. e5576-e5576).

Lee, H. (2013). 3D holographic technology and its educational potential. TechTrends, 57(4), 34-39.

Matere, I., Weng, C., Chien-Yu, C., \& Chi-Hao, C. (2021). The Opportunities and Challenges of Integrating Hologram Experiments into a Highly Visual Telepresence Course. Jurnal Pendidikan IPA Indonesia, 10(1), 1-14.

Matsika, C., \& Zhou, M. (2021). Factors affecting the adoption and use of AVR technology in higher and tertiary education. Technology in Society, 67, 101694.

Mishra, S. (2017). Hologram the future of medicine-From Star Wars to clinical imaging. Indian heart journal, 69(4), 566.

Nadila, N., Angriani, M. W., Utami, D. N., \& Nopita, D. (2021). Smart Three-Dimensional (3D) Hologram as an Innovative Teaching Tool in Virtual Learning Environment during Exigent Circumstances. Pancaran Pendidikan, 10(4).

Nur Arif Syazana, M. Z. (2019). The influence of self-esteem, healthy lifestyle and learning adaptability on the mental health among postgraduate students in University Utara Malaysia (UUM) (Doctoral dissertation, Universiti Utara Malaysia).

Parveen, K., \& Tran, P. Q. B. (2020). Practical problems for low quality education and steps needed for investment in public schools of Pakistan. Journal of Social Sciences Advancement, 1(01), 01-07. 
Parveen, K., Phuc, T. Q. B., Shafiq, M., \& Wei, T. X. (2021). Identifying the administrative challenges encountered by the principals in low-performing public secondary schools of Faisalabad District, Pakistan. International Journal of Humanities and Innovation (IJHI), 4(1), 5-16.

Phuc, T. Q. B., Nguyen, L. D., Parveen, K., \& Wang, M. (2020). Developing a theoretical model to examine factors affecting school leadership effectiveness. Journal of Social Sciences Advancement, 1(01), 16-29.

Pradhan, P., Mitra, P., Chowdhuri, S., Neogi, B., \& Ghosh, S. S. (2021). Postpandemic EdTech (Educational Technology) on Perspectives of Green Society. In Green Technological Innovation for Sustainable Smart Societies (pp. 39-66). Springer, Cham.

Ramachandiran, C. R., Chong, M. M., \& Subramanian, P. (2019). 3D hologram in futuristic classroom: A review. Periodicals of Engineering and Natural Sciences (PEN), 7(2), 580-586.

Shafiq, M., Zhang, Q., Akbar, M. A., Alsanad, A., \& Mahmood, S. (2020). Factors influencing the requirements engineering process in offshore software development outsourcing environments. IET Software, 14(6), 623-637.

Shafiq, M., Zhang, Q., Akbar, M. A., Khan, A. A., Hussain, S., Amin, F. E., ... \& Soofi, A. A. (2018). Effect of project management in requirements engineering and requirements change management processes for global software development. IEEE Access, 6, 25747-25763.

Taherdoost, H. (2016). Validity and reliability of the research instrument; how to test the validation of a questionnaire/survey in a research. How to test the validation of a questionnaire/survey in a research (August 10, 2016).

Venditti, C. P., \& Mele, P. (2020). How to Combine Virtual and Reality in Archaeology Communication: A Brief Overview of Mixed Reality and "Its Surroundings". Developing Effective Communication Skills in Archaeology, 245-258.

Wang, Y., Stein, D., \& Shen, S. (2021). Students' and teachers' perceived teaching presence in online courses. Distance Education, 42(3), 373-390.

Publisher's note: Science Impact Publishers remain neutral with regard to jurisdictional claims in published maps and institutional affiliations.

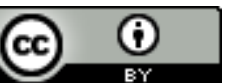

Open Access This article is licensed under a Creative Commons Attribution 4.0 International License, which permits use, sharing, adaptation, distribution and reproduction in any medium or format, as long as you give appropriate credit to the original author(s) and the source, provide a link to the Creative Commons license and indicate if changes were made. The images or other third-party material in this article are included in the article's Creative Commons license, unless indicated otherwise in a credit line to the material. If material is not included in the article's Creative Commons license and your intended use is not permitted by statutory regulation or exceeds the permitted use, you will need to obtain permission directly from the copyright holder. To view a copy of this license, visit https://creativecommons.org/licenses/by/4.0/.

(C) The Author(s) 2021 